\title{
Child malnutrition - from Hospital to clinical practice - the experience of Tanzania and Uganda
}

\author{
Desnutrição infantil - da teoria à prática clínica - a experiência da Tanzânia e Uganda
}

\author{
Alexandra Vasconcelos \\ Instituto de Higiene e Medicina Tropical - Institute of Hygiene and Tropical Medicine (IHMT), Universidade NOVA de \\ Lisboa, Rua da Junqueira Nº100, 1349-008 Lisboa, Portugal \\ Email: alexandravasc@gmail.com
}

\begin{abstract}
In recent years, there has been a global effort to tackle the problem of child malnutrition that is still the underlying cause of death of at least 3.1 million children annually. Uganda and Tanzania are among the 22 countries with higher prevalence of child malnutrition. However, these two countries are true examples of how it is possible to reduce this scourge through simple, low-cost strategies. In $2010 \mathrm{I}$ had the opportunity to learn and understand childhood malnutrition through a postgraduate course in Tanzania and Uganda - the East African Short Course in Tropical Medicine from London School of Hygiene and Tropical Medicine (LSHTM). Beginning with a review of concepts and definitions of childhood malnutrition and the links between development and nutrition, this article moves on to summarise a learning experience from Uganda and Tanzania related to the progress and effectiveness of 'hospital-based" and 'community-specific' interventions.
\end{abstract}

Keywords: malnutrition, childhood malnutrition, acute malnutrition, severe acute malnutrition (SAM), chronic malnutrition, stunting, East African Course in Tropical Medicine \& Hygiene, Tanzânia, Uganda, London School of Hygiene and Tropical Medicine (LSHTM), RUFT, Plumpy nut, hospital, community, refugee camp.

\section{Resumo}

Nos últimos anos tem havido um esforço global para combater o problema da desnutrição infantil, que ainda é causa de morte de pelo menos 3,1 milhões de crianças por ano. O Uganda e Tanzânia estão entre os 22 países com maior prevalência de desnutrição infantil. No entanto, estes dois países são verdadeiros exemplos de como é possível reduzir este flagelo através de estratégias simples e de baixo custo. Começando com uma revisão de conceitos e definições sobre a malnutrição infantil e as ligações entre o desenvolvimento e nutrição, este artigo passa por resumir uma experiência profissional pediátrica na área da desnutrição infantil na Tanzânia e Uganda possibilitada pelo East African Short Course in Tropical Medicine da London School of Hygiene and Tropical Medicine (LSHTM).

Palavras-chave: malnutrição, desnutrição infantil, desnutrição aguda, desnutrição aguda grave (DAG), desnutrição crónica, baixa estatura, East African Course in Tropical Medicine \& Hygiene, Tanzânia, Uganda, London School of Hygiene and Tropical Medicine (LSHTM), RUFT, Plumpy nut. 


\section{Introduction}

As of this writing, each night about 800 million people go to sleep hungry, and malnutrition is the underlying cause of death of at least 3.1 million children annually. Even though the right to food has been recognized since 1948 as a fundamental human right by the Universal Declaration of Human Rights (Article 25), this is still inaccessible to many (1)(2). Malnutrition in children is currently a global public health problem with wide implications, an unacceptable reality for the twenty-first century.

In order to achieve by 2030 the Goal 2 from the UN's Sustainable Development Goals (SDGs) (3-5), to end of all forms of hunger and malnutrition, including agreed targets on stunting and wasting in children under five years of age, a joint commitment and implementation of practical interventions are need in these resourcelimited settings. Effective intra- and inter-sectoral linkages must be put in place to promote coordination and resource utilization with scaling up of multi-sectoral interventions, placing more emphasis on communitybased initiatives that have proven to yield cost-effective results, as well as targeting areas and groups with the highest levels of malnutrition.

Uganda and Tanzania are among the 22 countries with higher prevalence of child malnutrition: Tanzania $\left(10^{\text {th }}\right)$ with $44 \%$ and Uganda $\left(14^{\text {th }}\right)$ with $38 \%$ of children with short stature (1). However, these two countries are true examples of how it is possible to reduce this scourge through simple, low-cost strategies.

In $2010 \mathrm{I}$ had the opportunity to learn and understand childhood malnutrition through a postgraduate course in Tanzania and Uganda - the East African Short Course in Tropical Medicine from London School of Hygiene and Tropical Medicine (LSHTM), in collaboration with Kilimanjaro Christian Medical College, Makerere University, Johns Hopkins University and the University of Washington. This was a two month, full time short course taught by LSHTM school staff and colleagues in Tanzania and Uganda and designed for doctors planning to work in Africa. The course allowed a true in-hand local experience, with the understanding of the everyday aspects surrounding clinical approach and public health issues facing doctors in Africa today. This text aims to share some personal experience which led to knowledge about the phenomenon of child malnutrition in developing countries.

\section{Introdução}

Todas as noites cerca de 800 milhões de pessoas adormecem com fome e a desnutrição é, anualmente, a causa subjacente de morte de, pelo menos, 3,1 milhões de crianças. Apesar do direito à alimentação ter sido constituído como um direito humano fundamental consignado desde 1948 na Declaração Universal dos Direitos Humanos (Artigo 25), este ainda é inacessível a muitos (1)(2)

A desnutrição infantil continua a ser um dos problemas mais importantes de saúde pública do mundo actual com vastas implicações, realidade inaceitável para o século XXI.

Para alcançar até 2030 o objectivo 2 dos Objectivos de Desenvolvimento Sustentável (ODS) (3-5) erradicar a fome e todas as formas de desnutrição, incluindo as metas acordadas para a baixa estatura e a desnutrição aguda nas crianças com menos de 5 anos de idade - é fundamental assumir o compromisso e implementar intervenções práticas nos países com recursos limitados. O Uganda e a Tanzânia são dos 22 países com maior prevalência de desnutrição infantil: a Tanzânia em $10^{\circ}$ lugar com $44 \%$ e o Uganda em $14^{\circ}$ com $38 \%$ de crianças com baixa estatura(1). A Tanzânia e o Uganda são, no entanto, bons exemplos de como é possível reduzir este flagelo através de estratégias simples e de baixo custo.

Em 2010, durante dois meses intensivos, tive a oportunidade de aprender e compreender este mundo da desnutrição através de um curso de pós-graduação na Tanzânia e Uganda - o East African Short Course in Tropical Medicine da London School of Hygiene and Tropical Medicine (LSHTM).

A descrição desta minha experiência vem então no sentido de partilhar um pouco do que me foi dado a conhecer sobre o fenómeno da malnutrição infantil nestes países. 


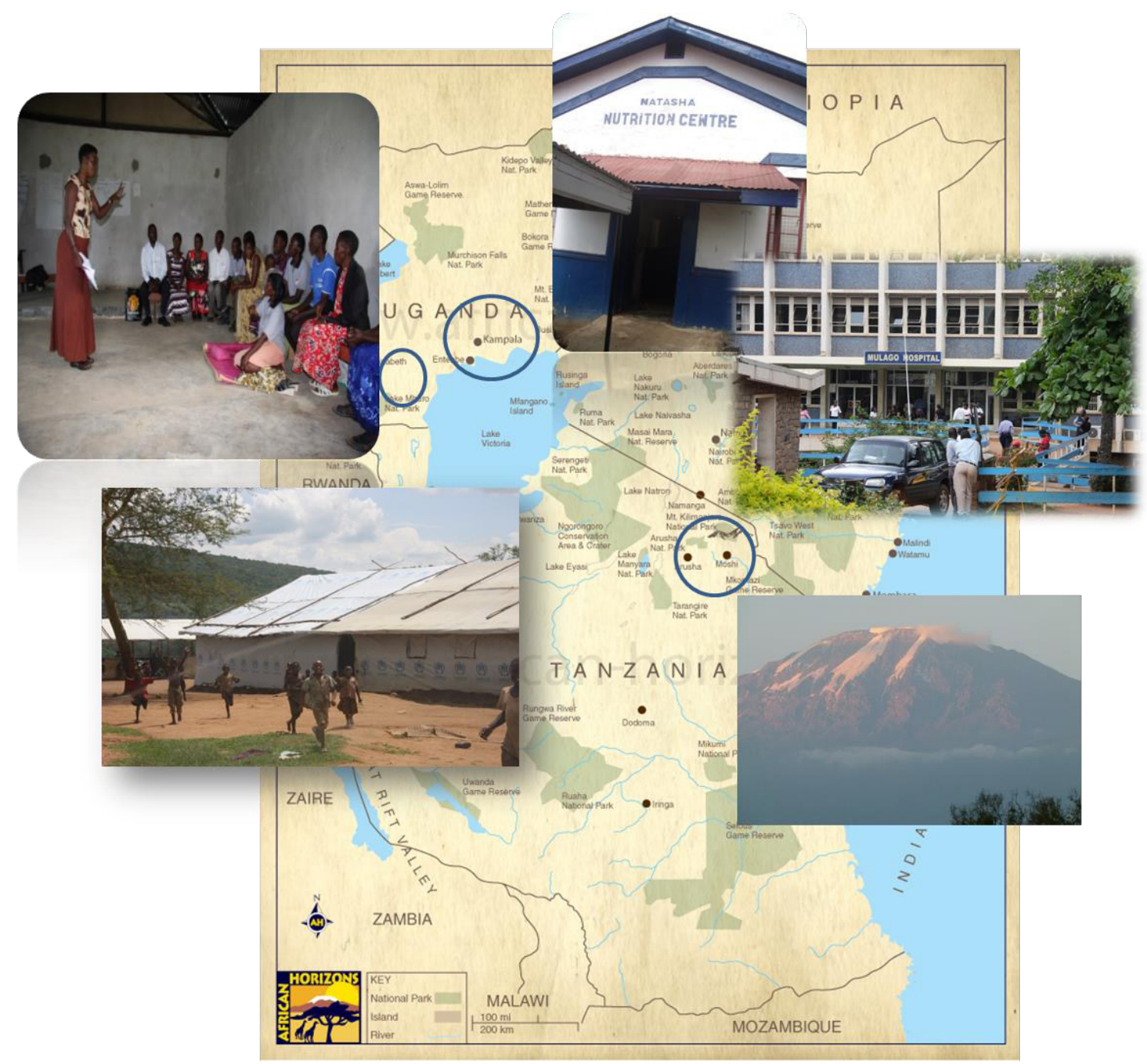

Figure 1/ Figura 1 - Teaching module of infant malnutrition in its different components - community hospital and a refugee camp: Tanzania and Uganda

Módulo de ensino de malnutrição infantil nas suas diferentes componentes - hospitalar, comunitária e em campo de refugiados: Tanzânia e Uganda

\section{East African Short Course in Tropical Medicine}

The East African course in TM\&H utilised the essence of the original London course and translated it in to an African context. The Tanzanian sessions were conducted at the Kilimanjaro Christian Medical College $(\mathrm{KCMC})$, a referral hospital for 11 million people with a 450 beds capacity. Oriented towards scientific research, the KCMC has several research centres, for example, in the areas of malaria, tuberculosis and HIV. The KCMC has also the Centre for Community Ophthalmology (KCCO) and the WHO Regional Dermatology Training Center collaborating for East Africa, and is one of the members of East African Consortium for Clinical Research (EACCR).

In Uganda, the experiences were more community-

\section{Curso breve Este-africano em Medicina Tropical}

O curso este-africano em medicina tropical utilizou a essência do curso original de Londres e traduziu-o para um contexto africano. As sessões na Tanzânia foram realizadas no Colégio Médico Cristão Kilimanjaro (KCMC), um hospital de referência para 11 milhões de pessoas com capacidade para 450 camas. Orientado para a investigação científica, o KCMC tem vários centros de investigação, por exemplo, nas áreas de malária, tuberculose e HIV. O KCMC conta também com o Centro de Oftalmologia Comunitária (KCCO) e o Centro Regional de Treinamento em Dermatologia da OMS que colaboram para a África Oriental e, é um dos membros do Consórcio de Pesquisa Clínica da África Oriental (EACCR). 
based, from Mbarara outreach activities were done in the remote village of Ruhunga Bwizibwera., A diversity of health related buildings are concentrated on Mulago Hill in the capital Kampala. The long rail limits the borders of this vast area with several centers: the old Mulago National Referral Hospital (1500 beds), Makerere University College of Health Sciences, the School of Public Health and, in contrast, as ultra-modern and technological as Infectious Diseases Institute (IDI) and the Baylor College of Medicine-Bristol-Myers Squibb Children's Hospital-Clinical Centre of Excellence.

Around two thirds of the course was focused on tropical infectious diseases, including TB, HIV and malaria. The remaining third was spent examining contemporary issues in East African healthcare, including the clinical assessment of infants and children, maternal health in resource-limited settings and an introduction to clinical epidemiology.

The curriculum was divided in to core and optional units. The optional weeks included student-selected units that allowed the opportunity to explore an area of policy or practice in more depth, which enabled me to choose malnutrition as well as refugee health care.

Regarding the child malnutrition programme, the approach included three different settings: hospital-based, community-based and a refugee camp. These different environments allowed me to learn a variety of clinical approaches.

\section{Outlining the Problem}

It is not easy to master all the concepts and definitions of child malnutrition. Concepts such as malnutrition, wasting, hunger, weight loss, failure to thrive and short stature belong to the same world, but reflect different situations. Definitions of malnutrition vary according to the perspective of the defining organisation. For example, the Food and Agriculture Organization (FAO) which, as dedicated to the production of food and access, defines it as failure in the intake of food energy needed to meet daily needs (2). The United Nations Children's Fund (UNICEF), on the other hand, focuses on child wellbeing, which leads to the choice of anthropometric evaluation as the preferred method to be used as a nutritional indicator (4).

According to the World Food Program, hunger is defined as the lack of sufficient food to meet energy needs. Hunger can lead to malnutrition, but the absence of
No Uganda, as experiências foram mais de base comunitária, realizando, a partir de Mbarara na remota aldeia de Ruhunga Bwizibwera, atividades de divulgação. Em Mulago Hill, na capital Kampala, estão concentrados vários edifícios relacionados com a saúde. A extensa linha de caminho de ferro limita as fronteiras desta vasta área com vários centros - o antigo Hospital Nacional de Referência Mulago (1500 camas), a Faculdade de Ciências da Saúde da Universidade de Makerere, a Escola de Saúde Pública e, por outro lado, edifícios ultramodernos e tecnológicos como o Instituto de Doenças Infecciosas (IDI) e o Colégio de Medicina da Baylor-Bristol-Myers Squibb Hospital Infantil e Centro de Excelência Clínica.

Cerca de dois terços do curso estão focados em doenças infecciosas tropicais, incluindo TB, HIV e malária. O restante dedica-se à análise de questões correntes e actuais dos cuidados de saúde da África Oriental, incluindo a avaliação clínica de lactentes e crianças e a saúde materna em locais de recursos limitados, e à introdução à epidemiologia clínica.

O currículo foi dividido em núcleo e unidades opcionais. E, nas semanas opcionais, foram incluídas unidades curriculares seleccionadas por alunos, oferecendo a oportunidade de explorar uma área mais política ou mais prática de forma mais aprofundada, o que, no meu caso, me permitiu escolher os temas da desnutrição, e os cuidados de saúde para refugiados.

Em relação ao programa de desnutrição infantil, a abordagem incluiu três configurações distintas -hospitalar, comunitária e em campo de refugiados, permitindo-me aprender uma variedade de abordagens clínicas.

\section{Delineando o Problema}

Não é fácil dominar todos os conceitos e definições da área da malnutrição infantil. Conceitos como malnutrição, desnutrição, fome, emagrecimento, má progressão ponderal, baixa estatura pertencem ao mesmo mundo mas traduzem situações diferentes. Na realidade, estas definições, por vezes, variam de acordo com o perspectiva da organização que a faculta, por exemplo, a Food and Agriculture Organisation (FAO) que, como se dedica à produção de alimentos e ao seu acesso, define-a como a falha na ingestão de alimentos energéticos necessários para satisfazer as necessidades diárias(2). A United Nations Children's Fund (UNICEF), por outro lado, foca-se no bem-estar da criança, o que leva a escolher a avaliação antropométrica como o método preferido a ser usado como indicador nutricional(4).

De acordo com o World Food Programe, a fome define-se como a falta de alimento suficiente para satisfazer as 
hunger does not imply the absence of malnutrition (5). Malnutrition, on the other hand, is the when a person's diet does not provide adequate nutrients for growth and maintenance or when a person is not able to adequately utilize the food consumed due to illness. Malnutrition encompasses both undernutrition (too thin, too short, micronutrient deficiencies) and 'overnutrition' (overweight and obesity), which may be ctually be considered 'unbalanced nutrition' as it often co-occurs with micronutrient deficiencies (5).

Going forward within this text I will try to answer to my own questions regarding child malnutrition, prior to this course, always adding the in-hand practical input from my various experiences in the field.

\section{Evaluating the nutritional status}

In paediatric practice, measuring is to compare. Anthropometry provides the single most portable, universally applicable, inexpensive and non-invasive technique for assessing the size, proportions and composition of the human body (6). It reflects both health and nutritional status and predicts performance, health and survival. Anthropometric indices are combinations of measurements. They are essential for the interpretation of measurements, as it is evident that a value for body weight alone has no meaning unless it is related to an individual's age or height (7).

In countries with good health systems, child growth monitoring is done through the most common anthropometric indices as weight-for-height, height-for-age, weight-for-age and body mass index (BMI) and head circumference-for-age (until 36th month of life). The BMI can easily determine the degree of undernutrition and "overnutrition", both in developed countries as in the developing ones (4) (12) (13).

The anthropometric indices can be expressed in terms of z-scores (Figure 2) or percentiles which can then be used to compare a child or group of children with a reference population. A z-score is a standard score showing how standard deviations are placed (over or under) the population mean distribution curve. The percentile shows the rank position of an individual on a given reference distribution, stated in terms of what percentage of the group the individual equals or exceeds. Thus a child of a given age whose weight falls in the $10^{\text {th }}$ percentile weighs the same or more than $10 \%$ of the reference population of children of the same age. Percentiles are commonly used in clinical settings because theirs interpretation is straightforward (6).

These indices allow to identify the types of malnutri- necessidades energéticas. A fome pode levar à desnutrição, mas a ausência de fome não implica ausência de desnutrição(5). A desnutrição, por outro lado, é a condição que resulta quando a dieta não fornece os nutrientes adequados para o crescimento ou quando uma criança não é capaz de utilizar adequadamente os alimentos consumidos devido à doença. A malnutrição, por outro lado, engloba tanto a desnutrição (criança muito magra, muito baixa ou com deficiências de micronutrientes) e a "supernutrição" (sobrepeso e obesidade), que deveria, no entanto, ser classificada como uma "nutrição desequilibrada", atendendo que muitas vezes cursa também com deficiências de micronutrientes(5).

\section{Avaliação do estado nutricional}

Na prática pediátrica, avaliar e medir é comparar. A antropometria é uma técnica extremamente portátil, universalmente aplicável, barata e não-invasiva para avaliar o tamanho, proporções e composição do corpo humano (6). Ela reflete tanto a saúde como o estado nutricional e prevê o desempenho, saúde e sobrevivência. Os índices antropométricos são combinações de medições. Eles são essenciais para a interpretação das medições, pois é evidente que um valor isolado de peso corporal não tenha significado a menos que este se relacione com a idade ou com a estatura da criança (7). Nos países com bons sistemas de saúde, a vigilância do crescimento infantil é feita através dos índices antropométricos mais comuns como peso-para-idade, comprimento/estatura-para-idade, peso-para-idade e índice de massa corporal (IMC) e o perímetro cefálico para a idade (até o $36^{\circ}$ mês de vida). O IMC pode facilmente determinar o grau de desnutrição e "supernutrição", tanto nos países desenvolvidos como nos em vias de desenvolvimento(4)(12)(13) .

Os índices antropométricos podem ser expressos em termos de z-scores (Figura 2) ou em percentis que podem então ser utilizados para comparar uma criança ou um grupo de crianças com uma população de referência. $\mathrm{O}$ z-score é uma escala padrão que indica como os desvio-padrão se situam (acima ou abaixo) em relação à normal distribuição da população.. O percentil indica a posição de um indivíduo em uma dada distribuição de referência, expressos em termos de percentagem do grupo. Assim, uma criança de uma determinada idade, cujo peso cai para o percentil 10 pesa o mesmo ou mais do que $10 \%$ da população de referência para uma criança da mesma idade. Os percentis são frequentemente usados na prática clínica já que permitem uma interpretação simples e clara (6). Estes índices permitem identificar os tipos de desnutrição que, de acordo com a OMS são, respectivamente, a 
tion which, according to the WHO are, respectively, the acute malnutrition or wasting (low weight for height), chronic or stunting (low height for age) and low-weight or underweight (low weight for age) if they are less than -2 z-scores of the reference/sex (3) (6). Malnutrition can still be classified as mild if $z$-score $<-1$ a -1.9 , moderate if the $z$-scores of the respective indicators meet between -2 and -3 and severe or serious if less than -3 .

There are therefore two different languages, the one that is used in daily clinical practice (percentiles), and the one expressed as z-scores used in the scientific world in most publications. desnutrição aguda ou wasting (baixo peso para a estatura), crónica ou stunting (baixa estatura para a idade) e baixo-peso ou underweight (baixo peso para a idade), caso sejam inferiores a -2 z-scores do valor de referência/sexo(3)(6). A desnutrição pode ainda ser classificada em ligeira se $\mathrm{z}$-score entre $<-1$ a -1.9 , moderada se $\mathrm{z}$-scores entre -2 e -3 e grave ou severa se inferior a -3 (6).

Há, portanto, duas linguagens diferentes, a que se utiliza na prática clínica diária (curvas de crescimento em percentis), e a expressa em z-scores divulgada no meio científico e na maioria das publicações.
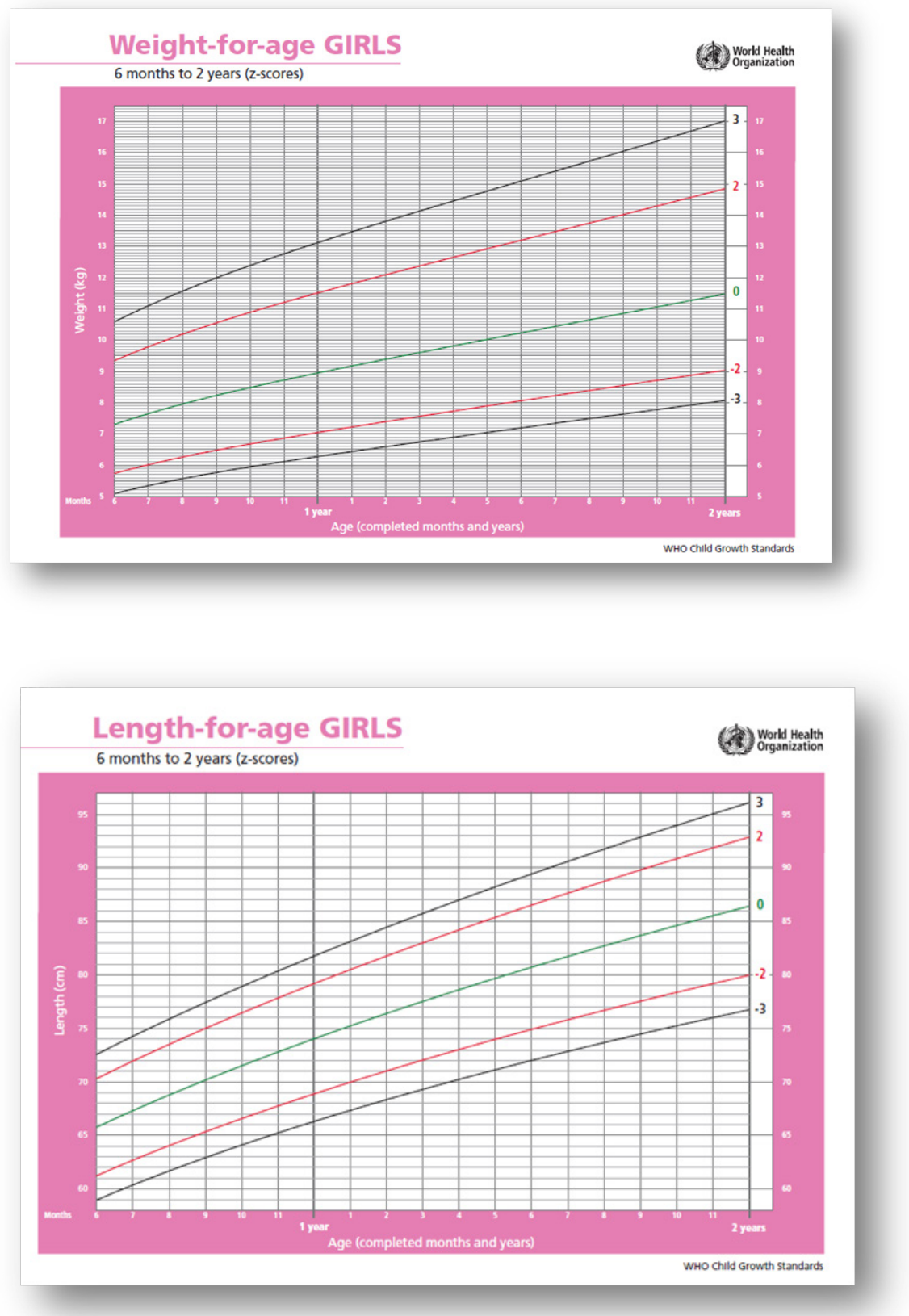

Figure 2/ Figura 2 - Growth curves of the WHO in z-scores: weight-for-age and height-for-age Curvas de crescimento da OMS em z-scores: peso-para-idade e estatura-para-idade 


\section{Evaluating the nutritional status in the field}

In developing countries, the anthropometric measure most commonly used is the weight-for-age, which is dependent only to the access to a scale. It enables a straightforward interpretation, easy, non-invasive and inexpensive, and further characterization of the nutritional status as low weight or failure to thrive. African health units are usually equipped with a scale, either the Salter suspended type, mechanical or electronic as Uniscale from UNICEF. In these countries, the main alarm is then the identification of children with poor weight progression, defined as weight-for-age below the $3^{\text {rd }}$ percentile or when slowing weight progression drops at least two percentiles in the curve (Figure 3).

Recently, mid-upper arm circumference (MUAC) has gained particular interest in the rapid diagnosis of severe acute malnutrition (SAM), as it effectively predicts the mortality risk compared with other anthropometric indexes (8). The use of MUAC is easy, fast to perform on large numbers of children, and is understandable to patients and staff. MUAC has greatly simplified the process of case identification and admission, simplified protocols, reduced staff workloads, and reduced training needs (8).

Continuous monitoring of the length/height, on the other hand, provides a linear growth process of the human body and is of utmost importance in determining the children's nutritional profile (7). However, in developing countries, as in Tanzania and Uganda, a lack of stadiometers (either horizontal to record the length of the infant or the vertical to measure children's height) is a reality in primary health care. This constraint does not allow the detection of children showing a growth rate of less than $4 \mathrm{~cm} /$ year at any age, which is always pathological, as well as their referral for investigation. The phenomenon of chronic malnutrition of children is poorly understood by health professionals in these countries without the height-for-age evaluations. Thus,simply providing stadiometers to these health centres will allow some kind of intervention in chronic malnutrition, as long as there is also training of health professionals in the handling and in the early diagnosis of cases of short stature, that is, chronic malnutrition or stunting.

Head circumference is an anthropometric parameter correlated with brain size, reflecting a child's growth. However, it also has its importance in the first two years of life as a nutritional indicator. Although considered as the anthropometric measure less affected by malnutrition, it is, however, the first to respond when adequate nutrient intake is provided (7). The assessment of this

\section{Avaliação do estado nutricional no terreno}

$\mathrm{O}$ índice antropométrico mais frequentemente utilizada nos países em desenvolvimento é o peso-para-idade, que é dependente apenas do acesso a uma balança. Permite a avaliação rápida, fácil, não invasiva e não dispendiosa do crescimento e ainda a caracterização do estado nutricional do tipo baixo peso ou má progressão ponderal. A globalidade dos postos e centros de saúde nestes países está apetrechada com uma balança, quer do tipo suspensa de Salter, mecânicas ou eletrónicas do tipo Uniscale da Unicef. Nestes países, o principal alarme vem então da identificação da criança com má progressão ponderal, definida quando o peso-para-idade inferior ao Percentil 3 ou quando há desaceleração da progressão ponderal com cruzamento/queda de pelo menos 2 percentis (Figura 3 ).

Recentemente, o perímetro braquial ou mid-upper arm circumference (MUAC) tem ganho particular interesse no diagnóstico rápido da desnutrição aguda grave (DAG), pois permite com facilidade e de forma eficaz predizer o risco de mortalidade comparativamente com os índices antropométricos(8). O uso do perímetro braquial é fácil, rápido de executar em um grande número de crianças e é compreensível tanto para os pais como para os profissionais de saúde. O MUAC simplificou muito o processo de identificação dos casos de DAG, critérios de admissão, protocolos simplificados, redução da carga de trabalho do pessoal e reduziu as necessidades de formação (13).

O registo da evolução do comprimento/estatura expressa, por outro lado, o processo de crescimento linear do corpo humano e é de extrema importância na definição do perfil nutricional da criança(7). Contudo, nos países em desenvolvimento, nomeadamente na Tanzânia e no Uganda, a inexistência de estadiómetros, quer os horizontais para registar o comprimento do lactente, quer os verticais para aferir a estatura das crianças é um facto nos cuidados de saúde primários. Este constrangimento impede que as crianças que apresentem uma velocidade de crescimento inferior a 4 centímetros/ano em qualquer idade, o que é sempre patológico, possam ser identificadas, assim como referenciadas para investigação. Os profissionais de saúde destes países têm então dificuldade em compreender o fenómeno da desnutrição crónica infantil nas suas crianças, já que este resulta da avaliação da estatura-para-idade que não é feita por inexistência dos estadiómetros. Deste modo para abordar o problema da desnutrição crónica nos países de recursos limitados há que disponibilizar os estadiómetros nos centros de saúde infantil e, simultaneamente, formar os profissionais de saúde no diagnóstico precoce dos 
parameter is also made inconsistently in resource-limited countries, an additional obstacle for monitoring the disease.

It is understandable, therefore, that the publications relating to the prevalence of stunting and wasting of leading organizations such as WHO, UNICEF, WFP, and FAO, among others, arise from community-based studies. These studies, on average, have a minimum of 400 participating children, which does not always reflect the nutritional situation of individual children in these countries (1). casos de baixa estatura, isto, é, de desnutrição crónica ou stunting.

O perímetro cefálico é um parâmetro antropométrico correlacionado com o tamanho cerebral, reflectindo o seu crescimento. No entanto, tem também a sua importância nos dois primeiros anos de vida como indicador nutricional. Embora seja considerado a medida antropométrica menos afectada pela desnutrição, é, no entanto, a primeira a responder quando se proporciona um aporte nutricional adequado(7). A avaliação deste parâmetro é também feito de forma inconsistente nos países de recursos limitados, sendo mais um entrave para a monitorização da doença.
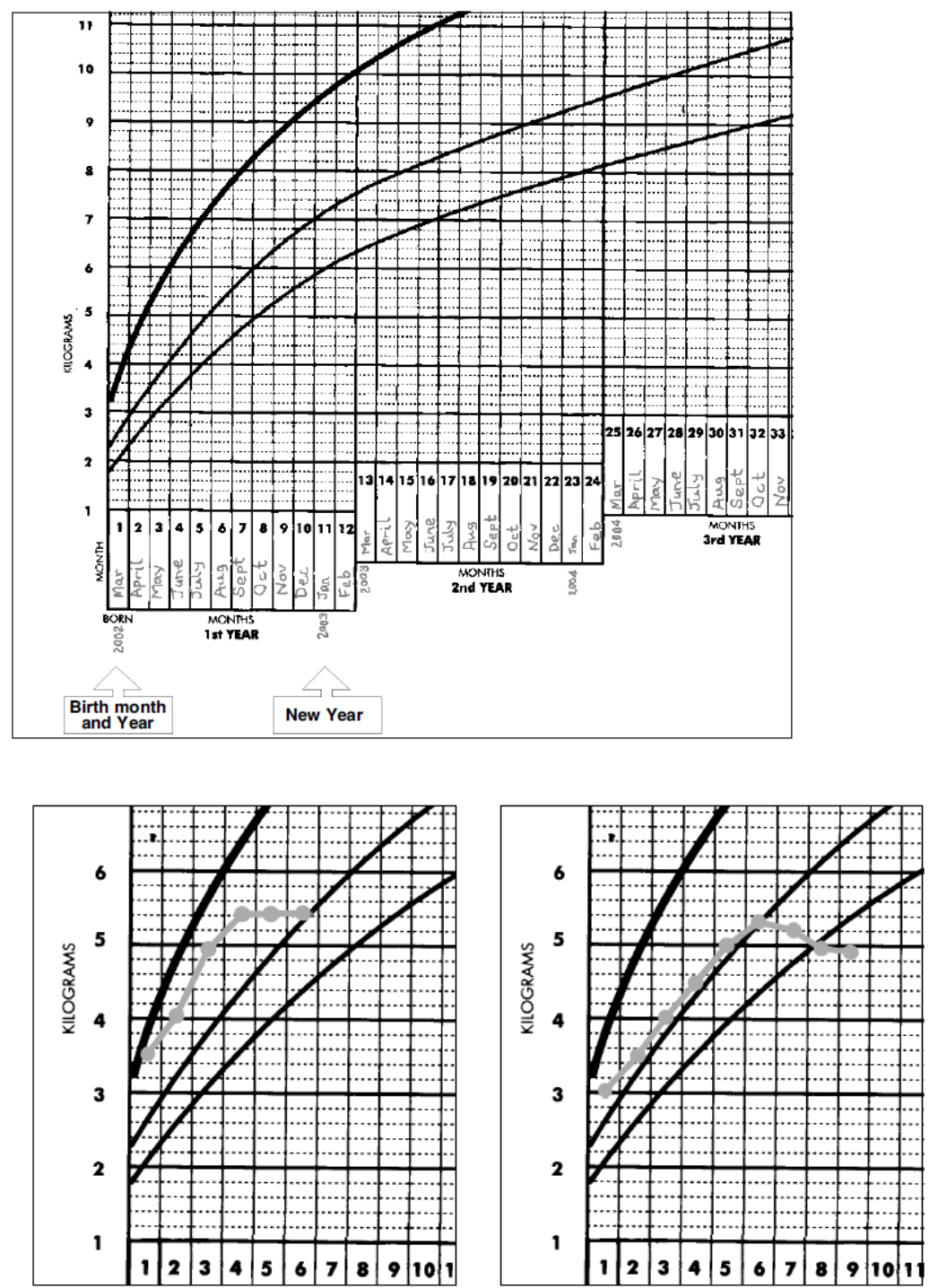

Figure 3/ Figura 3 - Growth curves of Uganda (weight-for-age) and two examples of bad weight progression (source: Ministry of Health Nutrition Section. Promoting Child Growth and Health in Uganda.

Training Handbook for Community Child Health Promoters. Uganda. 2003)

Curvas de crescimento do Uganda (peso-para-idade) e dois exemplos de má progressão ponderal (Fonte: Ministry of Health Nutrition Section. Promoting Child Growth and Health in Uganda. Training Handbook for Community Child Health Promoters. Uganda. 2003) 


\section{Malnutrition}

Malnutrition can begin early in the uterus (low birth weight or intrauterine growth restriction), but often has early onset in childhood, resulting from improper disruption of exclusive breastfeeding and late introduction of complementary food into infants' diets within the first two years of life (5) (10). It is also associated with repeated episodes of infectious diseases (respiratory and diarrheal diseases). Other risk factors include family socio-economic problems, inconsistent knowledge of mothers about child care (feeding, hygiene and general health care) and weak mother-child bonding (9) (10)(11).

Field experience has shown that, if on the one hand, the promotion of exclusive breast-feeding for the first six months of life of infants is crucial for their development and has a very important impact on reducing child mortality (12), on the other hand, the lack of campaigns to raise awareness on the importance of the appropriate age for the introduction of complementary food into infants' diets contributes to the delay of this important step, since mothers keep breastfeeding, almost exclusively, long after the recommended age. This has serious consequences because exclusive breast milk after the $6^{\text {th }}$ month of age is no longer sufficient to provide the nutrients and energy required to keep up with the infants' rapid growth. So, babies are often found with poor weight gain and iron deficiency anaemia due to the delay or improper introduction of complementary food, which can then cause neuropsychomotor development delay and, later, short stature.

Either acute or chronic malnutrition significantly impacts on child wellbeing. Acute malnutrition raises the risk for serious infections and mortality, while chronic has more subtle effects that translate into long-term functional losses, initially on physical growth, neuropsychomotor development, and other morbidities in childhood and later on, in adulthood, in low productive capacity and employment income (13)(14)(8).

We therefore recognize that each child has their own growth and maturation pattern and that the experiences that occur during the first 1000 days of life will have a definite impact on their biological and social behavior as an individual (5) (15).

\section{A desnutrição}

A desnutrição pode começar precocemente na vida intrauterina (baixo peso ao nascer ou restrição do crescimento intra-uterino), mas frequentemente tem início precoce na infância, decorrente da interrupção inadequada do aleitamento materno exclusivo e da introdução incorreta da alimentação complementar nos primeiros 2 anos de vida(5)(10). É associada ainda à ocorrência de repetidos episódios de doenças infecciosas (doenças diarréicas e respiratórias). Outros factores de risco na génese da desnutrição incluem problemas familiares relacionados com a situação socioeconómica, conhecimento precário das mães sobre os cuidados à criança (alimentação, higiene e cuidados com a saúde de modo geral) e o fraco vínculo mãe-filho(9)(10)(11). A experiência no terreno revelou que, se por uma lado, a promoção do aleitamento exclusivo durante os primeiros 6 meses de vida do lactente é crucial para o seu bom desenvolvimento e tem um impacto muito importante na redução da mortalidade infantil(12), paradoxalmente, a falta de campanhas de sensibilização para a importância do início da diversificação alimentar aos 6 meses leva as mães a atrasar essa etapa, já que mantêm a amamentação, de forma quase exclusiva muito após a idade recomendada. Esta situação tem graves consequências pois o leite materno deixa de ser suficiente para fornecer os nutrientes e energia requeridos para acompanhar o rápido crescimento do lactente após os 6 meses de vida. É então frequente encontrar lactentes com má progressão ponderal e com anemia ferropénica por este motivo, o que é extremamente preocupante nos primeiros dois anos de vida pois poderá condicionar atraso no desenvolvimento neuropsicomotor e posterior baixa estatura.

A desnutrição, quer a aguda quer a crónica, compromete pois, significativamente, a saúde da criança. A aguda aumenta o risco de infecções graves e de mortalidade, enquanto a crónica, com efeitos mais subtis, traduz-se em perdas funcionais a longo prazo, inicialmente no crescimento físico, no desenvolvimento neuropsicomotor e na presença de morbidades na infância e, posteriormente, na idade adulta, na baixa capacidade produtiva e de rendimento laboral(13)(14)(8).

Podemos pois reconhecer que cada criança tem o seu próprio padrão de crescimento e maturação e que as experiências que ocorrem nos seus primeiros 1000 dias de vida desde a concepção terão uma repercussão definitiva sobre o seu comportamento biológico e social como indivíduo(5)(15). 


\section{Acute malnutrition or wasting}

Acute malnutrition or wasting means that the weightfor-height Z-score less than -2.0 (16).

Acute malnutrition is caused by a recent and significant weight loss, which is often associated with severe food deprivation and/or serious illness (16)(17)(6). It is identified when the weight-for- height $\mathrm{z}$-score is less than -2 of the reference value from the WHO international growth chart. The prevalence of acute malnutrition is highest in sub-Saharan Africa and in India(14).

In relation to the arm circumference or MUAC, acute malnutrition ranks as serious if less than $115 \mathrm{~mm}$, moderate if greater than or equal to 115 up to $125 \mathrm{~mm}$, light if less than $125 \mathrm{~mm}$ and at risk of acute malnutrition if greater than or equal to 125 to less than $135 \mathrm{~mm}$ (17) (18).

There are two "academic" specific forms of severe acute malnutrition (SAM) in children, a non- oedematous type, also known as marasmus, and another, oedematous, called kwashiorkor. Marasmus is the serious wasting, that is, a child with extreme thinness, being defined by a weight-for-height $<-3$ z-scores or MUAC $<115 \mathrm{~mm}$ (8)(18). The child with kwashiorkor typically presents with severe acute malnutrition with bilateral edema. Kwashiorkor type malnutrition has often a fast installation, features hepatomegaly, cognitive disturbance, as well as hair and skin changes (11). Often related to the birth of a brother, before the child turns the first year of life, limiting the supply in breast milk and the mother's availability of the in feeding the other child.

The term marasmus-kwashiorkor is sometimes used to describe a child that presents serious thinness but also oedema. Recently these concepts have changed dramatically, however, it is still unknown why some children exhibit the oedematous type of malnutrition and if this can be associated, somehow, to a type of immunodeficiency (8).

\section{Chronic malnutrition, stunting or stunting}

Chronic malnutrition or stunting is defined as a heightfor-age Z-score less than -2.0 (16).

Compared with acute malnutrition, which appears in a short period of time and is reversible, short stature or stunting is a gradual and cumulative process that occurs during the first 1000 days from conception, that is, during the first two years of the child's life and it is irreversible (5). It follows a prolonged period of insufficient food intake and the occurrence of recurrent infections/ diseases or a combination of both. It implies a series of

\section{A desnutrição aguda ou wasting}

Desnutrição aguda ou wasting significa que o peso-para-estatura $<-2$ z-scores (16).

A desnutrição aguda é causada por uma perda recente e significativa de peso, que está frequentemente associada à privação alimentar acentuada e/ou doença grave(16)(17)(6). É identificada quando o peso-para-estatura é inferior a -2 z-scores do valor de referência/ sexo da tabela internacional de crescimento da OMS. A prevalência da desnutrição aguda é maior na África Subsaariana e na Índia(14).

Em relação ao perímetro braquial ou MUAC, a desnutrição aguda classifica-se em grave se $<115 \mathrm{~mm}$, moderada se $\geq 115 \mathrm{a}<125 \mathrm{~mm}$, ligeira se $<125 \mathrm{~mm}$ e em risco de desnutrição aguda se $\geq 125$ a $<135$ mm(17)(18).

Existem duas formas "académicas" de desnutrição aguda grave (DAG) nas crianças, uma do tipo não-edematosa, também conhecida como marasmo, e outra edematosa, denominada de kwashiorkor. O marasmo é o wasting grave, isto é, criança com magreza extrema, definindo-se actualmente por um peso-para-estatura $<-3$ z-scores ou um MUAC $<115 \mathrm{~mm}(8)(18)$. A criança com kwashiorkor é aquela que apresenta uma desnutrição aguda grave com edema bilateral. A desnutrição do tipo kwashiorkor, muitas vezes, de instalação rápida, apresenta diversas lesões desde hepatomegália, perturbação cognitiva, assim como alterações do cabelo e cutâneas (11). Muitas vezes relaciona-se com o nascimento de um irmão antes da criança completar o primeiro ano de vida, limitando o aporte em leite materno e a disponibilidade da mãe em alimentar a criança com kwashiorkor.

O termo marasmo-kwashiorkor é, por vezes, utilizado para descrever a criança que apresenta magreza grave mas também edema. Recentemente, estes conceitos mudaram dramaticamente mas ainda se desconhece por que motivo algumas crianças apresentam o tipo de desnutrição edematosa e se esta estará associada, de alguma forma, a um tipo de imunodeficiência (8).

\section{A desnutrição crónica, baixa estatura ou stunting}

Desnutrição crónica ou a baixa estatura define-se como uma estatura-para-idade $<-2$ z-scores(16).

Comparativamente à desnutrição aguda, que surge num curto intervalo de tempo e é reversível, a baixa estatura ou stunting é um processo gradual e cumulativo que ocorre durante os primeiros 1000 dias desde a concepção, isto é, durante os primeiros dois anos de vida da criança e é irreversível (5). Resulta quer de um prolongado e insuficiente aporte alimentar, quer da ocorrên- 
consequences, particularly in the failure to achieve the genetic potential of linear growth (16)(19)(20). In the short term, it represents an increase of morbidities and greater mortality risk; in the long run, it leads to adults of short stature, with lower cognitive performance, becoming an "inter-generational sentence". For females the stunting represents a greater risk of intra-partum complications and stillbirth due to the fetal-pelvic incompatibility, i.e. in pregnancy the short stature relates to a narrow pelvic girdle and subsequent difficulty of the normal progression of labor (15).

The indicator used in chronic malnutrition is the heightfor-age, as also calculated by comparing the height of a child with the international reference table of height growth of the WHO. Overall, about one in every four children under the age of five years presents short stature, and a higher proportion of adolescents and adults is faced with the consequences of having had short stature soon in early childhood (14). The higher prevalence of pre-school children with short stature is in sub-Saharan Africa and in Southeast Asia (1).

\section{The child with low weight or underweight}

Low weight or underweight is defined as weight-forage -score less than -2.0 (16).

The low weight is identified when the weight-for-age is less than -2 z-scores of the reference/value of WHO international growth curves. The low weight reflects chronic malnutrition or also acute malnutrition (5) (21). The burden of underweight in children under five years of age is alarming in sub-Saharan Africa and in South Asia (1) (5). As mentioned previously, this index is used in daily clinical practice in countries with limited resources, but is expressed in percentiles as the tables of the z-scores of the WHO are not used in clinical practice assistance.

\section{"Invisible malnutrition"}

Deficiencies in vitamins and micronutrients, especially vitamin A, iron, iodine and zinc (22) cause also a state of malnutrition. These shortcomings are the result of poor quality of diets and may also arise in the context of a disease that increase the needs, the use, or the loss of important micronutrients (1)(23). Iron deficiency and subsequent anaemia are global problems, with highest expression in the developing countries. This lack of vitamins and micronutrients is the expression of "invisible malnutrition" estimated to reach more than 2 bil- cia de infecções/doenças recorrentes ou de uma combinação de ambos. Implica uma série de consequências, sobretudo na falha em atingir o potencial genético de crescimento linear (16)(19)(20). A curto prazo, representa o aumento de morbidades e maior risco de mortalidade; a longo prazo, condiciona um adulto de baixa estatura, com menor desempenho cognitivo, transformando-se numa "sentença inter-geracional". No sexo feminino a baixa estatura representa um maior risco de complicações intra-parto e morte fetal pela incompatibilidade feto-pélvica, isto é, a baixa estatura da grávida relaciona-se com estreita cintura pélvica e dificuldade da normal progressão do trabalho de parto (15).

O indicador usado na desnutrição crónica é a estatura-para-idade, medida igualmente calculada comparando a estatura de uma criança com a tabela de referência internacional de crescimento em estatura da OMS. A maior prevalência de crianças em idade pré-escolar com baixa estatura é na África Subsaariana e no Sudeste-asiático (1).

\section{Definindo a criança com baixo peso ou underweight}

O baixo peso ou underweight é defenido como peso-para-idade <- 2 z-scores(16).

O baixo peso é identificado quando o peso-para-idade é inferior a -2 z-scores do valor de referência/sexo da tabela internacional de crescimento da OMS. O baixo-peso reflete quer a desnutrição crónica quer a desnutrição aguda(5)(21). Como anteriormente referido, este índice é o usado na prática clínica diária nos países com recursos limitados mas expresso em percentis já que as tabelas dos z-scores da OMS não são utilizadas na prática clínica assistencial.

\section{A “desnutrição invisível"}

As deficiências em vitaminas e micronutrientes, principalmente em vitamina A, ferro, iodo e zinco (22) provocam também um estado de malnutrição. Estas carências resultam de dietas de fraca qualidade ou podem também surgir no contexto de uma doença que aumente as necessidades, a utilização ou a perda de micronutrientes (1)(23). A carência de ferro e consequente anemia é um problema mundial, com maior expressão nos países em desenvolvimento. Esta carência de vitaminas e micronutrientes é a expressão da "desnutrição invisível" que assume proporções preocupantes, estimando-se que atinja mais de 2 mil milhões de pessoas (2), tendo um impacto negativo na vida dos indivíduos e das populações. 
lion people (2), and has a negative impact on the lives of individuals and populations.

\section{FROM THEORY TO PRACTICE: FROM HOSPI- TAL TO COMMUNITY EXPERIENCE}

\section{A brief look to the past...}

The inpatient treatment approach and initial efforts to treat large numbers of children with severe acute malnutrition emerged during the Ethiopia famine of the mid-70s with the first rehabilitation centres in refugee camps in Uganda (24). Initially, the treatment consisted of administering a mixture of dried skimmed milk, oil and sugar diluted into clean water. The importance to add potassium and magnesium to the diet of SAM children was later recognized. The children could gain weight as well as regain different functions of the body. Over the years, changes were made to this protocol; ready-made recovery diets, based on the same basic formula with the addition of an improved vitamin and mineral mix became available in the mid-90s and rapidly became widely used to minimize risk of errors in the preparation of these foodstuffs. Ready-to-consume diet formulas were introduced, initially, F-75, with sodium and lower protein content and, later, F-100 (4) (11).. With these new dietary protocols and relatively intensive medical care, recovery rates improved up to $75 \%$ and mortality rates were reduced to below $10 \%$ (11). From a clinical perspective, these protocols were considered as rather successful.

However, at the same time, the limitations of the inpatient model became clear. Although successful in terms of recovery of treated children, it failed to tackle SAM as a public health problem. Demand on staff and infrastructure were so large that the model was not sustainable. Coverage and accessibility were also identified as barriers, whereas the distant populations rarely could have access to these centres. At present, humanitarian agencies only establish the rehabilitation centres in Africa when there is a major crisis.

The strategy changed after 2005, moving the treatment of SAM from inpatient hospitals and feeding centres into the community with the creation of communitybased centres for identification and treatment of malnourished children - the Community-Based Management of Acute Malnutrition (CMAM) approach - with great emphasis on the involvement of the whole community.

The CMAM model emerged after several anthropological studies showed that most people did not understand the bio-medical model of inpatient model of SAM and

\section{DA TEORIA À PRÁTICA: DA EXPERIÊNCIA HOSPITALAR À COMUNITÁRIA}

\section{Um pouco de história...}

A abordagem hospitalar da criança com desnutrição aguda grave (DAG) é já conhecida desde 1950 e foi em 1970, com a fome na vizinha Etiópia, com a formação dos primeiros campos de refugiados no Uganda e com a criação de grandes centros de recuperação que se foi adquirindo experiência e know-how (24). Inicialmente o tratamento consistia em administrar uma mistura de leite em pó desnatado com óleo e açúcar diluídos em água limpa apelidada de "LOA". Foi nesta época que se reconheceu a importância de adicionar potássio e magnésio à dieta destas crianças. As crianças conseguiam ganhar peso bem como recuperar diferentes funções do organismo. Tornaram-se assim disponíveis as fórmulas de dieta de recuperação prontas a consumir: a inicial F-75, com menor teor de proteína e com sódio e, posteriormente, a F-100 (4)(11). Com estes novos protocolos dietéticos e avanço dos cuidados médicos, as taxas de recuperação passaram para $75 \%$ e as taxas de mortalidade foram reduzidas para menos de $10 \%$. Do ponto de vista clínico, estas medidas foram consideradas um sucesso. No entanto, simultaneamente, as limitações do modelo de internamento ficaram claras. Embora bem sucedido em termos de recuperação individual, não conseguiu enfrentar, como é óbvio, a dimensão da DAG como um problema de saúde pública.

O modelo de grandes centros de tratamento revelou-se pois insustentável, por requerer um grande número de profissionais de saúde e elevados custos para manter as infraestruturas. A acessibilidade foi igualmente identificada como um entrave, atendendo que as populações longínquas raramente conseguiam ter acesso a estes centros diferenciados. Assim, as agências humanitárias só estabelecem novamente os grandes centros de recuperação nutricional nestes moldes, em África, quando se verifica uma grande crise.

Foi a partir do ano de 2005 que surgiu a aposta na criação de centros de base comunitária para a identificação e abordagem da criança desnutrida, os Community-Based Management of Acute Malnutrition (CMAM) com grande ênfase no envolvimento de toda a comunidade. $\mathrm{O}$ modelo surgiu após vários estudos antropológicos revelarem as principais fragilidades e constrangimentos existentes à identificação e tratamento da DAG. Em primeiro lugar, como a população não compreendia as razões nem a instalação do quadro de desnutrição nas crianças, procurando, numa primeira fase, os médicos tradicionais da aldeia o que provocava incondicionalmente um atraso no início do tratamento e formas mais 
instead sought treatment with traditional practitioners (11). This prolonged the time to presentation, thereby increasing the frequency of complications. These studies also observed that the inpatient model, which separated families and took mothers and children away from husbands, siblings and farms was unpopular; and this unpopularity further delayed presentation and reduced compliance.

The decision to involve the community throughout the decision-making process and action was crucial to the adoption of the CMAM approach. The process consisted in detecting key individuals within the families and tribes, giving them access not only to information and education but also participation in the decision-making processes. This model proved to be of enormous success, substantially increasing the early detections of child malnutrition, enabling the existence of centres even in the most remote areas.

Therefore various community engaging actions were conducted. The key innovation underpinning this revolution in care was putting the responsibility in the community to do the early recognition, presentation and compliance of SAM children, as well as informing them in the proper techniques of use and correct interpretation of the arm circumference or MUAC (12) (25)(26).

This strategy enabled accessible and comprehensible SAM treatment, as well as early stage recognition of the disease, appropriate follow-up and a consequent reduction in the number of hospital admissions.

The results are huge improvements in program coverage and greatly reduced mortality rates that have made it possible today to have functional models in countries with limited resources, in that only about $15 \%$ of children require inpatient care and $85 \%$ can be followed in a community centre or treated at home. But these success rates could only be reached due to the availability of a valuable tool on a large scale - the therapeutic preparations ready to be consumed - the RUFT (Ready to Use Therapeutic Foods).

\section{Mbarara Hospital (Uganda) and Kilimanjaro Christian Medical College (Tanzania): the inpatient approach}

The post-graduation studies allowed me to see the effectiveness of these two models, the inpatient as well as the community one. The hospital approach to children with SAM was observed in Uganda in Mbarara Hospital paediatric ward and in Tanzania in the paediatrics department of KCMC. The clinical approach was first undertaken at the inpatient ward of the hospital, and graves de doença. Estes estudos também observaram que o internamento hospitalar, ao separar as famílias por longos períodos, afastando as mães, das restantes crianças e do marido, tornou-se impopular, o que protelava ainda mais o diagnóstico e tratamento.

A decisão de envolver a comunidade ao longo de todo o processo de decisão e actuação foi crucial para o seu envolvimento. $\mathrm{O}$ processo consistiu em detectar indivíduos-chave no seio das famílias e tribos, dando-lhes acesso não só a informação e educação assim como à participação na tomada de decisão. Este modelo revelou-se de enorme sucesso, aumentando substancialmente as detecções precoces de desnutrição infantil, possibilitando a existência de centros mesmo em áreas mais remotas.

Foram, assim, realizadas várias acções comunitárias preciosas. De destacar, pela sua relevância, a passagem da responsabilidade da detecção dos casos para a comunidade, o ensino para saúde como forma de reconhecimento precoce da desnutrição, aliado à formação das técnicas de uso e correcta interpretação do perímetro braquial ou MUAC (12)(25)(26).

Esta estratégia possibilitou que o tratamento passasse a ser acessível e compreensível havendo um ganho significativo no maior número de referenciações em fase precoce da doença, conseguindo-se um seguimento da criança com desnutrição em casa, e consequente diminuição do número de internamentos hospitalares prolongados.

Desta forma, actualmente é possível ter modelos funcionais em países com recursos limitados, em que apenas cerca de $15 \%$ das crianças necessitem de cuidados em internamento e $85 \%$ possam ser seguidas num centro comunitário ou tratadas no seu domicílio. Mas estas taxas de sucesso só puderam ser alcançadas após o aparecimento, em larga escala, de preparações alimentares terapêuticas prontas a serem consumidas - as RUFT (Ready to Use Therapeutic Foods).

\section{Mbarara Hospital (Uganda) e Kilimanjaro Chris- tian Medical College (Tanzânia): a abordagem hospitalar}

A experiência profissional que tive nestes dois países permitiu-me então testemunhar a eficácia destes dois modelos adaptados às situações clínicas específicas de cada criança. A abordagem hospitalar à criança com DAG foi feita no Uganda, na enfermaria de pediatria do Mbarara Hospital e na Tanzânia no serviço de pediatria do KCMC. A actuação clínica era faseada, entre o internamento durante a fase crítica e o posterior acompanhamento durante a fase de recuperação nos centros derecuperaçãonutricional. 
subsequent monitoring during the recovery phase was done in the nutritional rehabilitation centres.

The first step in approaching a child with SAM consists of checking for the existence of complications. Complications can be innumerous, but mostly include signs of infection, metabolic changes, severe oedema and/or anorexia/food intolerance. In cases were complications are detected, or in case of marasmus or kwashiorkor, the inpatient approach at the hospital is always an inevitability.

Children with 'uncomplicated' SAM are clinically well, alert and have retained their appetite. They should usually be managed as outpatients where suitable services with access to ready-to-use therapeutic food (RUTF) exist.

\section{Malnutrition and infection}

The diagnosis and management of infection are often different in malnourished versus well- nourished children.

\section{Outpatient treatment}

Regardless of where the child is treated, we must always take into consideration that the administration of antibiotics in children with SAM is crucial, even when there is no clinical evidence of infection. The rationale for this is that (i) malnourished children frequently have bacterial infections, generally, Salmonella sp. and E. coli ; (ii) diagnosing infection in malnourished children is difficult because clinical manifestations of infection (e.g. fever) may not be apparent; and (iii) malnourished children frequently have bacterial overgrowth in their small bowel (8)(13).

If the child is treated as an outpatient, current evidence suggests that amoxicillin $80-90 \mathrm{mg} / \mathrm{kg} /$ day in two divided doses for seven days is the most appropriate treatment, or cefdinir (3rd generation cephalosporin) at a dose of $14 \mathrm{mg} / \mathrm{kg} /$ day (8)(24). The 2013 study in Malawi reinforces this statement by identifying a reduction of mortality at 12 weeks to $4.8 \%$ for the oral amoxicillin and $4.1 \%$ for cefdinir against a placebo with $7.4 \%$ mortality (13)(27). This substantial mortality reduction in children without overt infection and eligible for outpatient treatment in a rural area suggests that the provision of antibiotics should remain routine (and critically important) in all settings where SAM is managed outside of hospitals, regardless of the presence of features of infection (13).
A abordagem à criança com DAG passa por verificar, numa primeira etapa, a existência de complicações. Classificando como complicação a existência de sinais de infecção, alteração metabólica, edema grave e/ ou anorexia/intolerância alimentar. Nas situações que cursam com complicações, ou nos casos de marasmos ou kwashiorkor, o internamento é sempre uma inevitabilidade.

A criança sem complicações apresenta bom estado geral, boa vitalidade com apetite preservado. São estas as elegíveis para uma abordagem comunitária ou em ambulatório, sendo o tratamento à base dos RUTF.

\section{Desnutrição e infecção}

O diagnóstico e tratamento das infecções difere entre crianças malnutridas e bem nutridas. Independentemente do local em que a criança é tratada, há que ter sempre em consideração, que a administração de antibioticoterapia nestas situações é crucial, mesmo quando não existe evidência clínica de infecção. A desnutrição está intrinsicamente relacionada com a infecção, sendo esta a principal causa de alta mortalidade nestas situações (13). A desnutrição aguda grave associa-se a (i) uma elevada frequência de bacteriémia, geralmente, a Salmonella sp. e a E. coli ; (ii) a uma dificuldade em diagnosticar a presença de infecção por ausência de sintomas, isto é, por inexistência de febre devido à deficiência imunológica presente nestas crianças e (iii) por último, porque a desnutrição condiciona um sobrecrescimento bacteriano no intestino delgado (8). As razões expostas permitem corroborar que se deva iniciar antibioticoterpia empírica em todas as criança com DAG, independentemente da existência ou não de sinais de infecção.

Se a criança for tratada em ambulatório, o antibiótico deverá ser a amoxicilina oral na dose de 80 a $90 \mathrm{mg} /$ $\mathrm{kg} /$ dia, de 12 em 12 horas, durante 7 dias ou a cefdinir (cefalosporina de $3^{\mathrm{a}}$ geração) na dose de $14 \mathrm{mg} / \mathrm{kg} / \mathrm{dia}$ (24). O estudo de 2013 no Malawi veio reforçar esta indicação, identificando uma redução da mortalidade às 12 semanas de $4.8 \%$ para a amoxicilina oral e de $4.1 \%$ para a cefdinir contra placebo com $7.4 \%$ (13)(27). Esta redução substancial da mortalidade em crianças elegíveis para a abordagem comunitária e sem infecção evidente reforça que se deverá continuar a administrar por rotina antibioticoterapia empírica a todas as crianças com SAM tratadas fora dos hospitais, independentemente da presença de características de infecção (13). As crianças com critérios de internamento devem iniciar esquema de antibioticoterapia dupla, de acordo com a OMS, com ampicilina intravenosa durante 2 dias 


\section{Inpatient treatment}

According to WHO's guidelines, children with inpatient criteria must start ampicillin (parenterally for two days followed by enteral amoxicillin/ampicillin for a further five days) and gentamicin (parenterally for 7 days) (13). There are authors who question this recommendation, bearing in mind a basic tenet of paediatric care that IV antibiotics should be switched to oral sooner rather than later in order to minimize discomfort and nosocomial infection risk from indwelling devices and the inherent immune deficiency of malnourished children, as well as the risk of renal toxicity associated with gentamicin (13)(24).

Metronidazole is an antibiotic with anti-anaerobic and some anti-protozoal activity.It is active against $\mathrm{Gi}^{-}$ ardia, which is widespread in children with SAM in some settings. In a small study from the Gambia, $45 \%$ of severely acutely malnourished children with chronic diarrhoea had giardiasis, along with $27 \%$ of malnourished children without diarrhea (13). Metronidazole is also active against small intestinal bacterial overgrowth due to achlorhydria, reduced gut motility and impaired absorption of sugars in malnourished children, with a potential role for treatment necessary from unhygienic food preparation practices (13). Metronidazole is therefore recommended, mostly in children with persistent diarrhea, at a reduced dose of $12 \mathrm{mg} / \mathrm{kg} /$ day (or lower dose), in three divided doses for seven days.

Currently, it is also being investigated if the provision of a six month co-trimoxazole prophylaxis, analogous to that provided for HIV-infected children, impacts mortality during 12 months in HIV-uninfected children aged $2-59$ months admitted to the hospital with SAM (13).

In these clinical situations we must avoid the administration of Paracetamol (also called acetaminophen) or ibuprofen in children with SAM, as the elimination of paracetamol is considerably prolonged in severely malnourished children with significant risk of hepatic damage. Ibuprofen, on the other hand, it is not recommended in children with dehydration due to potential impact on renal function and gastric bleeding (13).

The inpatient management of children with SAM is complex, requiring meticulous practice of care, and it is also essential to consider the possibility of the coexistence of other infections or diseases that may cause or exacerbate the SAM, in particular, tuberculosis, HIV, malaria, urinary tract infection, pneumonia, skin infections and intestinal parasites (11) (13)(28). seguidos de amoxicilina com ácido clavulânico, por via oral, durante 5 dias em conjunto com gentamicina intravenosa durante 7 dias (13). Há autores que questionam esta recomendação tendo em conta o risco acrescido de adquirir uma bacteriemia nosocomial, atendendo aos 7 dias com cateter e à inerente deficiência imunitária das crianças desnutridas. Estes defendem a transição, o mais precoce possível, da antibioticoterapia dupla para a via oral, evitando, desta forma, não só o risco das infecções nosocomias como também o risco de toxicidade renal associado à terapêutica com gentamicina (13) (234).

A terapêutica com metronidazol é igualmente recomendada, principlamente na criança com diarreia persistente, na dose de $12 \mathrm{mg} / \mathrm{kg} / \mathrm{dia}$ (ou em dose inferior), de 8 em 8 horas durante 7 dias. Ao ser um antibiótico com actividade anti-anaeróbica e alguma actividade anti-protozoária tem a vantagem de tratar a giardíase e o sobrecrescimento bacteriano do intestino delgado, resultado da acloridria, motilidade reduzida e má absorção dos hidratos de carbono patentes nesta doença. De salientar que um estudo na Gâmbia indicou que 45\% das crianças com DAG com diarreia crónica estavam infectadas com Giardia e que $27 \%$ das crianças com DAG mas sem diarreia tinham também giardíase (13). Actualmente, está também a ser investigado se as crianças com DAG internadas beneficiariam de um esquema profilático, durante 6 meses, com co-trimoxazole, na mesma linha de raciocínio do que se pratica na criança com VIH, de forma a reduzir a mortalidade por infecção a 12 meses nos casos de crianças com DAG sem VIH submetidas a internamento(13).

Nestas situações clínicas há que evitar administrar paracetamol ou ibuprofeno nas crianças com DAG, visto que a eliminação do paracetamol está prolongada na DAG, potencializando os riscos de intoxicação hepática e o ibuprofeno, por outro lado, não é recomendado nas crianças com desidratação devido ao risco de lesar a função renal e causar hemorragia gástrica (13).

A abordagem hospitalar da criança com DAG é complexa, requer meticulosa prática assistencial, sendo imprescindível equacionar igualmente a possibilidade da coexistência de outras infecções ou doenças que possam estar a condicionar ou a agravar a DAG, nomadamente, a tuberculose, VIH, malária, infecção urinária, pneumonia, infecções cutâneas e parasitoses intestinais (11)(13)(28). 


\section{The nutritional rehabilitation center and the mira- cle called Plumpy Nut ${ }^{\circledR}$}

As soon as there are no immediate risks for children, they should be discharged to carry out their treatment at nutritional recovery centers as inpatient or as outpatients. In the nutritional rehabilitation center Natasha Nutrition Centre in Mbarara-Uganda, the cooks taught us to prepare a special homemade recipe, the LOA (milk, oil and sugar) equivalent to the formula F100, as well as other calorie richpurees of peanut with spinach, tomato and pumpkin, nicknamed "homemade RUFT". The novelty was to be introduced to a new RUFT, Plumpy Nut ${ }^{\circledR}$, a nutritional package consumed directly by the child without the addition of water. The removal of water from the RUTF recipe avoids the dangers of contamination by bacteria, making this food safe. Described as the find of the century in the fight against malnutrition, it is a ready-to-eat peanut butter with a high protein and energy content (92 g per package are equivalent to $500 \mathrm{kcal}$ ), and also contains vitamins $\mathrm{A}, \mathrm{B}$ complex, $\mathrm{C}, \mathrm{D}, \mathrm{E}$ and $\mathrm{K}$ and minerals such as calcium, phosphorus, potassium, magnesium, zinc, copper, iron, iodine, sodium, and selenium. It is an energy "bomb" that in two weeks of use allows children to be able to recover from a state of severe malnutrition, while maintaining continued nutritional support at home. This discovery also resulted in a huge economic advantage, as the duration of treatment with Plumpy Nut ${ }^{\circledR}$ with the administration of two to three packs a day for four weeks represents a cost of only 12 euros per child.

\section{Village Health Team}

As mentioned above, these countries have achieved significant improvements because they have developed effective strategies to combat child malnutrition through community programs for early detection, thus preventing the appearance of more severe cases of acute malnutrition.

I had the privilege to understand the eminent role of the communities' engagement through the remarkable experience of knowing the work of the Canadian NGO Healthy Child Uganda (HCU). I was taken by van to the remote village of Ruhunga Bwizibwera where the elements of the Village Health Team (VHT) were already gathered for their monthly training. The VHT members are ordinary people from different communities of the region that volunteer to this prestigious role, so recognized by each tribe. HCU's mission is to enable each member to play an important mission as a community health agent, given that these are regions in

\section{O Centro de Recuperação Nutricional pediátrico e o milagre chamado Plumpy Nut ${ }^{\circledR}$}

Logo que possível, as crianças já sem risco imediato, mantêm o seu tratamento nos centros de recuperação nutricional, quer em internamentos de curta duração quer de forma ambulatória. No centro de recuperaçãonutricional, no Natasha Nutrition Centre, em Mbarara - Uganda, as cozinheiras ensinaram a preparar a receita caseira, o LOA (leite, óleo e açúcar) equivalente à fórmula F100 da OMS, assim como outros purés calóricos à base de miolo de amendoim com espinafres, tomate e abóbara, os apelidados "homemade RUFT".

A novidade esteve em travar conhecimento com o referido RUFT, o pacote nutricional Plumpy Nut ${ }^{\circledR}$ consumido directamente pela criança sem a adição de água. A eliminação de água a partir da receita RUTF evita os perigos de contaminação por bactérias, tornando este alimento seguro. Descrito como a descoberta do século no combate à desnutrição, é uma pasta de amendoim pronta a consumir com elevado teor proteico e energético (92 g por pacote equivalem a $500 \mathrm{kcal}$ ), contendo também vitaminas $\mathrm{A}$, complexo $\mathrm{B}, \mathrm{C}, \mathrm{D}, \mathrm{E}$ e $\mathrm{K}$ e os minerais como cálcio, fósforo, potássio, magnésio, zinco, cobre, ferro, iodo, sódio e selénio; uma "bomba" energética que em 2 semanas permite que as crianças consigam recuperar do seu estado de desnutrição grave, mantendo o apoio nutricional continuado em casa. Também se traduziu numa vantagem económica, pois a duração do tratamento com o Plumpy Nut ${ }^{\circledR}$ com a administração de 2 a 3 embalagens por dia durante quatro semanas de tratamento representa apenas um custo de 12 euros por criança.

\section{Village Health Team - Equipa de Saúde na Comu- nidade}

Como anteriormente referido, estes países atingiram francas melhorias por terem desenvolvido estratégias eficazes de combate à desnutrição infantil, através dos programas comunitários para a detecção precoce, prevenindo o aparecimento dos casos de desnutrição aguda com maior gravidade.

O papel exímio das comunidades foi-me dado a conhecer através da experiência marcante de ter acompanhado uma ONGD Canadiana, a Healthy Child Uganda (HCU). Numa carrinha chegámos à remota aldeia de Ruhunga Bwizibwera onde os elementos da Village Health Team (VHT) se reuniam para a sua formação mensal. São cidadãos comuns provenientes de diferentes comunidades da região que se voluntariam para este prestigiante papel, assim reconhecido por cada tribo. A 
which there are no health professionals. The members are then taught the techniques for early identification of child malnutrition. VHT elements are also responsible for many other community activities, such as: mapping the health villages, basic care of wounds and burns; perform maneuvers of basic life support, identification of the alarm signals of the pregnant, newborn and child health, and the administration of medication, including the anti-retroviral drugs. The methodology used by the HCU is extraordinary because it encourages the use of music, songs and theatrical representations to teach the formal content. There is no better way to never forget the signs of malnutrition in children than to learn them in the form of songs. The sound produced by all the elements singing with enthusiasm is unforgettable. Indeed, in oral tradition, folk songs are the best communication tools.

\section{Refugee camp, the Nakivale Refugee Camp}

The perception of chronic malnutrition was most evident during a week inside Uganda, in the module titled Rural and Migrant Healthcare. Here I was provided a chance to understand the dynamics of the refugee camps and the fight against their main threats: measles and cholera. I will keep as a memorable moment the day I arrived to the Nakivale Refugee Camp and entered into a tent where refugees from former Zaire lived and in fractions of seconds, I was surrounded by hundreds of children jumping and laughing, approaching me with a shiny overwhelming curiosity. Although these children may live safely for several years, it was evident to me that their first 1000 days of life, between conflicts, hunger, and diseases, had condemned them to a short stature that is no longer reversible.

\section{Conclusion}

The growth of the human body is a complex process with different speeds during the various stages of life, and it is recognised that the first 1000 days of life from conception are not only the most important ones but also the most vulnerable.

Child malnutrition, whether acute or chronic, compromises the health of the child, and the next generations, however, it is possible to act on its prevention. The knowledge of the phenomenon made possible the missão da HCU é capacitar cada membro para desempenhar a missão de agente de saúde na comunidade a que pertence, atendendo que se tratam de regiões em que nem um enfermeiro existe. Nestas formações são-lhes ensinadas as técnicas para realizarem a identificação precoce da desnutrição infantil. Os elementos da VHT são também responsáveis por muitas outras actividades comunitárias, como por exemplo, pelo mapeamento sanitário das aldeias; pelos cuidados básicos de feridas e queimaduras; pelas manobras de suporte básico de vida; pela identificação dos sinais de alarme da grávida, do recém-nascido e da criança e pela administração de medicação, incluindo os anti-retrovirias. A metodologia utilizada pela HCU é extraordinária pois incentiva o uso da música, de canções e de representações teatrais para ensinar os conteúdos formais. Nada melhor, para jamais esquecer as listas dos sinais de desnutrição na criança, do que aprendê-los sob a forma de canções. De facto, em povos de tradição oral, as canções são os melhores instrumentos de comunicação.

\section{Campo de refugiados, o Nakivale Refugee Camp}

A percepção da desnutrição crónica foi mais evidente durante a semana passada no interior do Uganda, no módulo intitulado Rural and Migrant Healthcare. Uma oportunidade de entender a dinâmica dos campos de refugiados e a luta contra as suas principais ameaças: o sarampo e a cólera. Inesquecível o momento em que entrei numa tenda do Nakivale Refugee Camp onde vivem os refugiados do antigo Zaire e que, em fracções de segundos, fui rodeada por centenas de crianças que saltitantes e aos risos tentavam desesperadamente aproximarem-se de mim, traduzindo no seu olhar brilhante uma curiosidade esmagadora. Pese embora estas crianças vivam em segurança já há vários anos, é visível que os seus primeiros 1000 dias de vida, entre conflitos, fome e doenças, os condenaram a uma baixa estatura que já não é reversível.

\section{Conclusão}

O crescimento do corpo humano é um processo complexo com diferentes velocidades durante as várias fases de vida, reconhecendo-se actualmente que os primeiros 1000 dias de vida desde a concepção são, não só, os mais importantes para a criança como também os mais vulneráveis.

A desnutrição infantil, quer a aguda quer a crónica, compromete a saúde da criança, da população e das próximas gerações, no entanto, é possível agir na sua 
identification of specific and sensitive interventions to nutrition that have the ability to reduce the phenomenon, thus contributing to the optimization of long-term health. The examples from Tanzania and Uganda can be solutions to be implemented in countries with similar characteristics. Whereas the world has approximately 1.82 billion children between 0 and 14 years, we must take action to create a world in which access to food, nutrition and health is a reality for all.

This experience corroborated my notion that clinical activity in Africa must always follow standards and algorithm approaches specific to the characteristics of the field.

I hope that this text can contribute to a better clinical awareness and practice for all those who think or wish to have a professional period dedicated to the care of malnourished children.

For all those who daily face the harsh reality of clinical assistance to malnourished children in countries with limited resources, I express my highest consideration.

\section{Conflict of interests}

The authors declare that there is no financial or personal relationship that can be understood as presenting a potential conflict of interest. prevenção. O conhecimento do fenómeno possibilitou a identificação de pacotes de intervenções específicas e sensíveis para a nutrição que têm a capacidade de a reduzir, contribuindo para a optimização da saúde a longo prazo. Os exemplos da Tanzânia e do Uganda podem ser soluções a serem implementadas em países com características semelhantes. Considerando que actualmente o mundo tem aproximadamente 1,82 mil milhões de crianças entre 0 e 14 anos, há que exercer pressão e actuar no sentido de criar um mundo em que o acesso à alimentação, nutrição de qualidade e saúde seja uma realidade para todas as crianças.

A passagem por esta experiência corroborou a minha noção de que a actividade clínica em África passa por normas, algoritmos e atitudes terapêuticas muito especiais e individualizadas ao terreno dos países com recursos limitados.

A todos aqueles que imaginam ou desejam passar um período profissional dedicado às doenças tropicais e à saúde da criança africana, espero que esta partilha dê largas à vossa ambição e um incentivo para a partida com um melhor conhecimento sobre como olhar e abordar a desnutrição infantil.

Para todos aqueles que diariamente enfrentam a dura realidade da assistência clínica, quer hospitalar quer comunitária, a crianças desnutridas em países com recursos limitados, expresso a minha maior consideração.

\section{Conflito de Interesses}

Os autores declaram que não têm relações financeiras ou pessoais que possam ser entendidas como apresentando um conflito potencial de interesses. 


\section{References/ Referências}

1. UNICEF. Division of Communication. Tracking progress on child and maternal nutrition: a survival and development priority. 2009. 1-124 p.

2. FAO. FAOSTAT: FAO Statistical Programme of Work. Faostat [Internet]. 2013; Available from: http://faostat.fao.org/

3. Lima SC, et al. Segurança Alimentar e Nutricional na Comunidade dos Países de Língua Portuguesa: Desafios e Perspectivas. CPLP, Rio de Janeiro, 2012.

4. Duggan MB. Prevention of childhood malnutrition: immensity of the challenge and variety of strategies. Paediatr Int Child Health [Internet]. 2014;34(4):271-8. Available from: http://www.maneyonline.com/doi/full /10.1179/2046905514Y.0000000139

5. World Food Programme. 2015 - WFP and Nutrition. 2015;(September)

6. Duggan MB. Anthropometry as a tool for measuring malnutrition: impact of the new WHO growth standards and reference. Ann Trop Paediatr. 2010;30(1):1-17.

7. Rito A, et al. Guia de Avaliação do Estado Nutricional Infantil e Juvenil. Dgs-Insa. 2011.

8. Rytter MJH, Kolte L, Briend A, Friis H, Christensen VB. The Immune System in Children with Malnutrition-A Systematic Review. PLoS One [Internet]. 2014;9(8):e105017. Available from: http:// www.pubmedcentral.nih.gov/articlerender.fc gi? artid $=4143239 \&$ tool=pmcentrez\&rendert ype $=$ abstract

9. A, Nutrição. Manual de atendimento da criança com desnutrição grave em nível hospitalar. Ministério da Saúde. Brasil. 2005. 144 p.

10. Coulter JBS. Nutrition and malnutrition in low- and middle-income countries. Paediatr Int Child Health [Internet]. 2014;34(4):2335. Available from: http://www.maneyonline.com/doi/abs/10.1179/204690471 4Z.000000000214

11. Briend A, Collins S. Therapeutic nutrition for children with severe acute malnutrition summary of African experience. Indian Pediatr. 2010;47(8):655-9.

12. Loewenberg S. Breaking the cycle: drought and hunger in Kenya. Lancet [Internet]. Elsevier Ltd; 2014;383(9922):1025-8. Available from: http://linkinghub.elsevier.com/ retrieve/pii/S014067361460492X
13. Jones KDJ, Berkley J a. Severe Acute Malnutrition and Infection. Paediatr Int Child Health. 2014;(April 2013):1-29

14. Prendergast AJ, Humphrey JH. The stunting syndrome in developing countries. Paediatr Int Child Health. 2014;34.4:250-265;

15. Black RE, Victora CG, Walker SP, Bhutta ZA, Christian P, de Onis M, et al. Maternal and child undernutrition and overweight in low-income and middle-income countries. Lancet [Internet]. 2013;382(9890):427-51. Available from: http://linkinghub.elsevier. com/retrieve/pii/S014067361360937X

16. de Onis M, Onyango AW, Borghi E, Garza C, Yang H. Comparison of the World Health Organization (WHO) Child Growth Standards and the National Center for Health Statistics/ WHO international growth reference: implications for child health programmes. Public Health Nutr [Internet]. 2006;9(07):942-7. Available from: http://www.journals.cambridge.org/abstract_S1368980006001534

17. Golden MH. Evolution of nutritional management of acute malnutrition. Indian Pediatr. 2010;47(8):667-78

18. World Health Organization, Childrens Fund United Nations. WHO child growth standards and the identification of severe acute malnutrition in infants and children. 2009;11. Available from: http://apps.who.int/iris/bitst ream/10665/44129/1/9789241598163_eng. pdf

19. Fonseca LE, Carvalho A De, Groce N, Challenger E, Berman-Bieler R, Farkas a., et al. Prevention of childhood malnutrition: immensity of the challenge and variety of strategies. Paediatr Int Child Health [Internet]. 2014;34(4):271-8. Available from: http:// www.maneyonline.com/doi/abs/10.1179/20 46905514Y.0000000139

20. Tomkins A. Tackling undernutrition in children - new opportunities for innovation and action. Paediatr Int Child Health [Internet]. 2014;34(4):235-8. Available from: http:// www.maneyonline.com/doi/full/10.1179/20 46904714Z.000000000216

21. Emery PW. Metabolic changes in malnutrition. Eye (Lond) [Internet]. 2005;19(10):1029-34. Available from: http:// www.ncbi.nlm.nih.gov/pubmed/16304580
22. Branca F, Ferrari M. Impact of micronutrient deficiencies on growth: The stunting syndrome. Ann Nutr Metab. 2002;46(suppl 1):8-17.

23. Krebs NF, Miller L V, Michael Hambidge $\mathrm{K}$. Zinc deficiency in infants and children: a review of its complex and synergistic interactions. Paediatr Int Child Health [Internet]. 2014;34(4):279-88. Available from: http:// www.ncbi.nlm.nih.gov/pubmed/25203844

24. Brewster DR. Inpatient management of severe malnutrition: time for a change in protocol and practice. Ann Trop Paediatr. 2011;31(2):97-107.

25. The World Bank. Tanzania Nutrition at Glance. Japan Trust Fund scaling Up Nutr Report. 2015;

26. Ministry of Health Nutrition Section. Promoting Child Growth and Health in Uganda. Training Handbook for Community Child Health Promoters. Uganda. 2003.

27. Trehan I, Goldbach HS, LaGrone LN, Meuli GJ, Wang RJ, Maleta KM, et al. Antibiotics as part of the management of severe acute malnutrition. N Engl J Med [Internet]. 2013;368(5):425-35. Available from: http:// www.pubmedcentral.nih.gov/articlerender. fcgi ?artid $=3654668 \&$ tool $=$ pmcentrez\&rend ertype $=$ abstract

28. Picot, Joanna, et al. "The effectiveness of interventions to treat severe acute malnutrition in young children: a systematic review." Health Technology Assessment 2012; Vol. 16: No. 19 DOI: $10.3310 /$ hta16190

\section{Recommended Web pages:}

2013 WHO Guideline: updates on the management of severe acute malnutrition in infants and children (http://apps. who.int/iris/bitstream/10665/95584/1/9789241506328_eng.pdf)

2005 WHO Pocketbook of Hospital Care for Children. (http://www.who.int/maternal_child_adolescent/documents/child_hospital_care/en/index.html)

Kilimanjaro Christian Medical College: http://www.kcmc.ac.tz Nakivale Refugee Camp: http://www.hiiraan.com/ news $2 / 2008 /$ jan/uganda_somalis_living_in_the_nakivale_refugee_settlement.aspx

Healthy Child Uganda: http://www.healthychilduganda.org

Mulago National Referral Hospital: http://www.mulago.or.ug/ 